\title{
Teaching NeuroImages: Imaging features of DCC-mediated mirror movements and isolated agenesis of the corpus callosum
}

Timothy J. Edwards, MBBS,* Ashley P.L. Marsh, PhD,* Paul J. Lockhart, PhD, Linda J. Richards, PhD, and Richard J. Leventer, MBBS, PhD

Neurology ${ }^{\circledR}$ 2018;91:e886-e887. doi:10.1212/WNL.0000000000006085

\section{Correspondence}

Dr. Leventer

Richard.Leventer@rch.org.au

Figure T1-weighted MRI and color fractional anisotropy (FA) maps
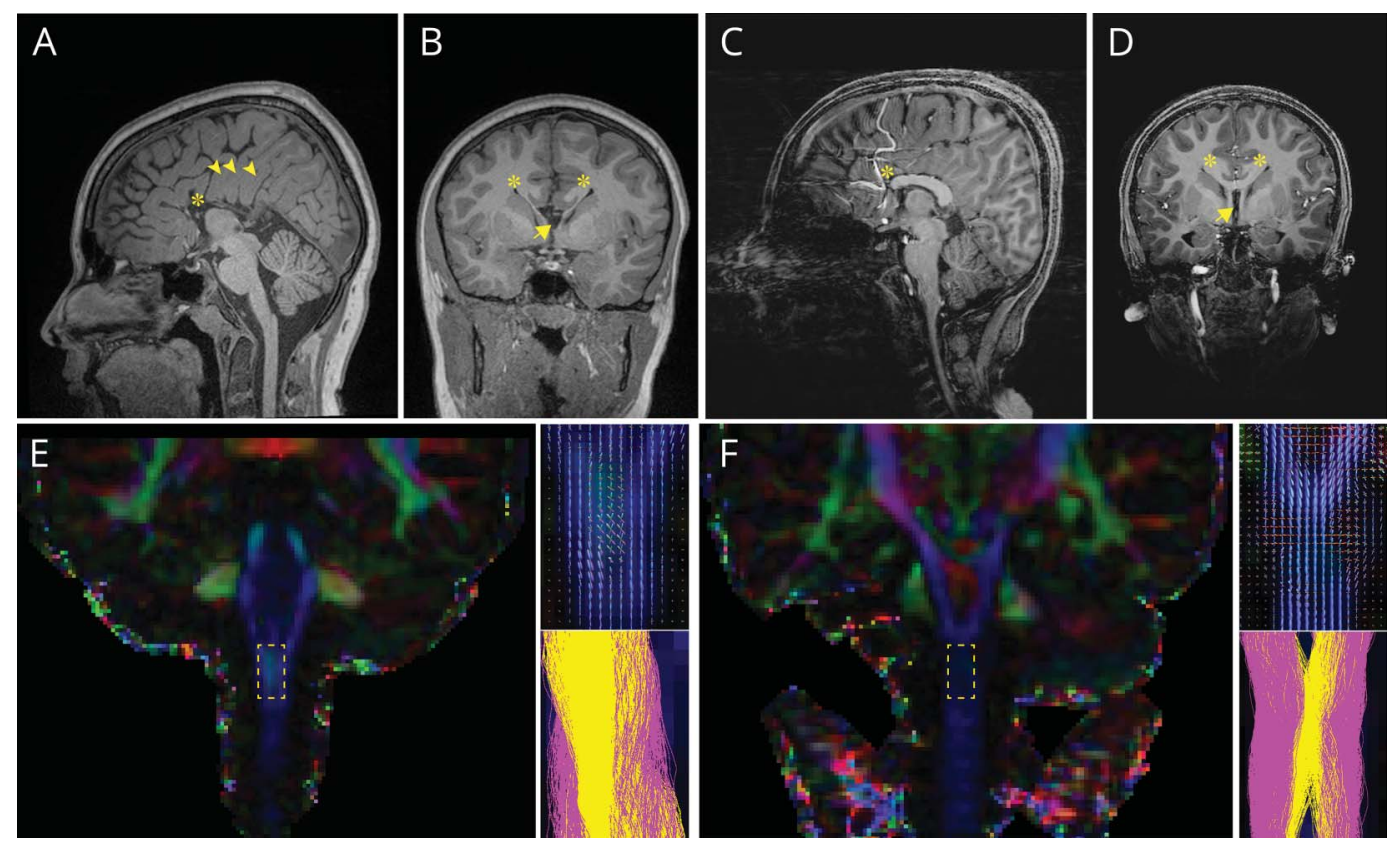

MRI shows complete (A, B) and partial (C, D) isolated agenesis of the corpus callosum with radial gyri and absence of the cingulate gyrus (arrowheads, A), unfused and thickened septum pellucidum (arrows, B and D) and Probst bundles (asterisks, B and D). Neurotypical (E) and DCC $+/-(F)$ color FA maps show decreased corticospinal decussation (bottom inset: yellow/crossed, purple/uncrossed) and corresponding fiber orientation distribution (top insets).

Two unrelated children were prenatally diagnosed with isolated agenesis of the corpus callosum (iACC) in otherwise uneventful pregnancies. Postnatal clinical assessments identified mirror movements in these offspring, their siblings, and their respective mothers. MRI (figure) showed characteristic features of complete (A, B) and partial (C, D) iACC, and abnormal crossing of the corticospinal tracts (E, F) on diffusion imaging. Sequencing revealed monoallelic missense mutations in the axon guidance receptor DCC. ${ }^{1}$ The association of iACC and abnormal corticospinal decussation is unique to only a handful of genes known to cause agenesis of the corpus callosum, ${ }^{2}$ and can provide a clinical clue towards a genetic diagnosis.

\section{MORE ONLINE}

\section{$\rightarrow$ Teaching slides}

links.lww.com/WNL/

A645

*These authors contributed equally to this work.

From the Queensland Brain Institute (T.J.E., L.J.R.), Faculty of Medicine (T.J.E.), and School of Biomedical Sciences (L.J.R.), The University of Queensland, Brisbane; Bruce Lefroy Centre for Genetic Health Research (A.P.L.M., P.J.L.) and Neuroscience Research Group (R.J.L.), Murdoch Children's Research Institute, and Department of Neurology (R.J.L.), Royal Children's Hospital; and Department of Paediatrics (A.P.L.M., P.J.L., R.J.L.) University of Melbourne, Parkville, Victoria, Australia.

Go to Neurology.org/N for full disclosures. Funding information and disclosures deemed relevant by the authors, if any, are provided at the end of the article. 


\section{Author contributions}

Dr. Edwards: study concept and design, analysis and interpretation. Dr. Marsh: study concept and design, analysis and interpretation. Dr. Lockhart: critical revision of the manuscript for important intellectual content. Dr. Richards: critical revision of the manuscript for important intellectual content, study supervision. Dr. Leventer: study concept and design, acquisition of data, critical revision of the manuscript for important intellectual content, study supervision.

\section{Study funding}

No targeted funding reported.

\section{Disclosure}

The authors report no disclosures relevant to the manuscript. Go to Neurology.org/ $\mathrm{N}$ for full disclosures.

\section{References}

1. Marsh APL, Heron D, Edwards TJ, et al. Mutations in DCC cause isolated agenesis of the corpus callosum with incomplete penetrance. Nat Genet 2017;49:511-514.

2. Edwards TJ, Sherr EH, Barkovich AJ, Richards LJ. Clinical, genetic and imaging findings identify new causes for corpus callosum development syndromes. Brain 2014;137:1579-1613. 


\section{Neurology}

\section{Teaching NeuroImages: Imaging features of $D C C$-mediated mirror movements and isolated agenesis of the corpus callosum}

Timothy J. Edwards, Ashley P.L. Marsh, Paul J. Lockhart, et al. Neurology 2018;91;e886-e887

DOI 10.1212/WNL.0000000000006085

This information is current as of August 27, 2018

\section{Updated Information \&} Services

References

Subspecialty Collections

Permissions \& Licensing

Reprints including high resolution figures, can be found at: http://n.neurology.org/content/91/9/e886.full

This article cites 2 articles, 0 of which you can access for free at: http://n.neurology.org/content/91/9/e886.full\#ref-list-1

This article, along with others on similar topics, appears in the following collection(s):

All Genetics

http://n.neurology.org/cgi/collection/all_genetics

Developmental disorders

http://n.neurology.org/cgi/collection/developmental_disorders DWI

http://n.neurology.org/cgi/collection/dwi

Motor Control

http://n.neurology.org/cgi/collection/motor_control

MRI

http://n.neurology.org/cgi/collection/mri

Information about reproducing this article in parts (figures,tables) or in its entirety can be found online at:

http://www.neurology.org/about/about_the_journal\#permissions

Information about ordering reprints can be found online:

http://n.neurology.org/subscribers/advertise

Neurology $®$ is the official journal of the American Academy of Neurology. Published continuously since 1951, it is now a weekly with 48 issues per year. Copyright @ 2018 American Academy of Neurology. All rights reserved. Print ISSN: 0028-3878. Online ISSN: 1526-632X.

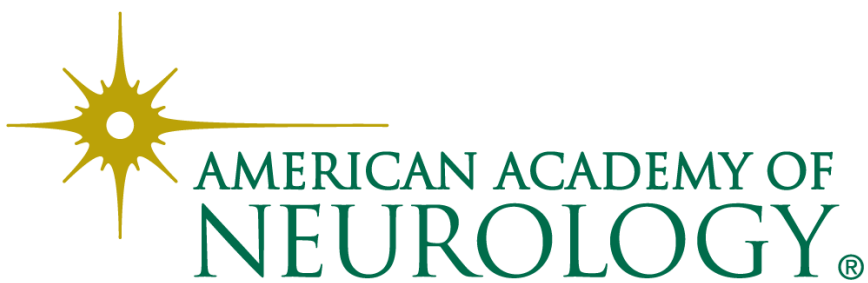

